\title{
FAKTOR-FAKTOR DETEKSI DINI KANKER LEHER RAHIM PADA WANITA USIA SUBUR DALAM
}

\author{
Dewi Suraya, Rachmawati, Serilaila \\ Politeknik Kesehatan Kementerian Kesehatan Bengkulu, Jurusan Kebidanan \\ Jalan Indragiri Nomor 3 Padang Harapan Bengkulu \\ d.suraya13@gmail.com
}

\begin{abstract}
Cervical cancer is a women's health problem in Indonesia, due to high incidence and mortality. The incidence of Cervical Cancer in Indonesia is 16 per 100,000 women. Not performing early detection of cervical cancer on a regular basis and on time is a factor in the spread of cervical cancer. The purpose of this study was to determine the factors that affect WUS in early detection of cervical cancer in Babatan Public Health Center. This research design uses a quantitative approach with cross sectional design. The population in this study is Women Age Fertile in Babatan Public Health Center area 2016. The sample used is 87 people with sampling technique using accidental sampling. Data collection techniques using questionnaires. Analysis of univariate data, bivariate using Chi Square test statistic and Independent sample $\mathrm{T}$ Test and multivariate using Logistic Regression. 87 WUS, 51.7\% good knowledge, 55.2\% negative attitude, 58.6\% less information exposure, $51.7 \%$ higher education and average age of 33 years old. Bivariate analysis showed that there was a correlation between knowledge, attitude, exposure of information and education with early detection of cervical cancer at Babitis Public Health Center 2016. Factor for early detection of cervical cancer is exposure of information.It is suggested that health officers should work together with cadres to socialize and improve the extension to the community repeatedly in every activity, especially for people with low education, so that people want to do early detection of cervical cancer with IVA and papsmear.
\end{abstract}

Keywords : Early Detection of Cervical Cancer, IVA, Papsmear

\begin{abstract}
Abstrak : Kanker leher rahim merupakan masalah kesehatan perempuan di Indonesia, sehubungan dengan angka kejadian dan angka kematian yang tinggi. Insiden Kanker Leher Rahim di Indonesia sebesar 16 per 100.000 perempuan. Tidak melakukan deteksi dini kanker leher rahim secara teratur dan tepat waktu merupakan faktor terjangkitnya kanker leher rahim. Tujuan penelitian ini adalah untuk mengetahui faktor-faktor yang mempengaruhi WUS dalam deteksi dini kanker leher rahim di wilayah Puskesmas Babatan.Desain penelitian ini menggunakan pendekatan kuantitatif dengan rancangan cross sectional. Populasi dalam penelitian ini adalah Wanita Usia Subur di wilayah Puskesmas Babatan tahun 2016. Sampel yang digunakan sebanyak 87 orang dengan teknik pengambilan sampel menggunakan accidental sampling. Analisis data univariat, bivariat menggunakan uji statistik Chi Square dan Independent sampel T Test dan multivariat menggunakan Regresi Logistik. 51,7\% pengetahuan baik, 55,2\% sikap negatif, 58,6\% keterpaparan informasi kurang, 51,7\% pendidikan tinggi dan rata-rata umur WUS 33 tahun. Ada hubungan antara pengetahuan, sikap, keterpaparan informasi dan pendidikan dengan deteksi dini kanker leher rahim di wilayah puskesmas Babatan Tahun 2016. Faktor yang paling berpengaruh terhadap deteksi dini kanker leher rahim adalah keterpaparan informasi.Disarankan pada petugas kesehatan sebaiknya bekerja sama dengan kader untuk mensosialisasikan dan meningkatkan penyuluhan kepada masyarakat secara berulang-ulang disetiap kegiatan terutama pada orang yang pendidikan rendah, sehingga masyarakat mau melakukan deteksi dini kanker leher rahim dengan IVA maupun papsmear.
\end{abstract}

Kata Kunci : Deteksi Dini Kanker Leher Rahim, IVA, Papsmear 
Kanker serviks atau kanker leher rahim adalah penyakit keganasan dari leher rahim (serviks) yang disebabkan oleh virus HPV (Human Papiloma Virus). Di seluruh dunia, penyakit ini merupakan jenis kanker ke dua terbanyak yang diderita perempuan setelah kanker payudara namun menjadi penyebab pertama kematian perempuan akibat kanker (WHO, 2007).

Terdapat beberapa metode skrining dan deteksi dini kanker leher rahim yaitu tes pap smear, IVA, kolposkopi, servikografi, thin prep dan tes HPV (Wilgin dkk, 2011). Mayoritas perempuan yang didiagnosi kanker leher rahim biasanya tidak melakukan deteksi dini atau tidak melakukan tindak lanjut setelah ditemukan adanya hasil abnormal. Tidak melakukan deteksi dini secara reguler merupakan faktor terbesar penyebab terjangkitnya kanker leher rahim pada seseorang.

Berdasarkan data Subdit Kanker Direktorat Pengendalian Penyakit Tidak Menular (PPTM) Kemenkes RI sejak tahun 2007-2014, program deteksi dini kanker leher rahim telah berjalan pada 1.986 Puskesmas di 304 kabupaten/kota yang berada di 34 provinsi di Indonesia. Cakupan skrining yang telah dilakukan sebanyak 909.099 orang $(2,45 \%)$, dengan hasil IVA positif sebanyak 44.654 orang (4,94\%), suspek kanker leher rahim sebanyak 1.056 orang (1,2 per 1.000 penduduk). Hal ini menunjukkan bahwa cakupan deteksi dini masih jauh dari target program yaitu 50\% perempuan berusia 30 50 tahun yang dicapai pada tahun 2019 (Buletin jendela data \& Informasi kesehatan, 2015).

Berdasarkan profil Provinsi Bengkulu tahun 2014, terdapat 0,93\% yang positif lesi prakanker di provinsi Bengkulu. Tahun 2015 naik menjadi 5,02\%. Berdasarkan laporan tahun 2015 di Kabupaten Selumaterdapat sebanyak
9,85\% positif lesi prakanker. Dari 6 Puskesmas yang melakukan pemeriksaan deteksi dini kanker leher rahim dengan metode IVA, puskesmas Babatan termasuk terendah WUS yang melakukan pemeriksaan IVA. Tahun 2014 hanya 6\%yang sudah melakukan pemeriksaan IVA. Sedangkan tahun 2015 sebesar 3\% yang sudah menjalani pemeriksaan IVA dengan positif lesi prakanker 3 kasus dan tahun 2016 terdapat 1 kasus kanker leher rahim yang tidak melakukan deteksi dini. Hal ini menunjukkan penurunan cakupan deteksi dini kanker leher rahim dengan metode IVA di Puskesmas Babatan (Profil Kesehatan Puskesmas Babatan, 2015).

Berdasarkan uraian latar belakang diatas rendahnya cakupan pemeriksaan deteksi dini kanker leher rahim di Puskesmas Babatan, yaitu 3\% masih jauh dibawah target yang ditentukan. Dan kurangnya pengetahuan akan bahaya kanker leher rahim, kurangnya informasi tentang penyakit kanker dan deteksi dininya. Tujuan penelitian ini untuk mengetahui faktor-faktor yang mempengaruhi WUS dalam deteksi dini kanker leher rahim di wilayah Puskesmas Babatan.

\section{BAHAN DAN CARA KERJA}

Desain penelitian ini menggunakan pendekatan kuantitatifdengan rancangan penelitian cross sectional. Data dalam penelitian ini adalah data primer dan data sekunder. Data primer diperoleh secara langsung dari WUS dengan mengguakan kuesioner, sedangkan data sekunder diperoleh dari laporan tahunan IVA di Puskesmas Babatan. Data univariat dianalisis secara deskriptif, sedangkan data bivariat dengan chi-square $95 \% \mathrm{CI}$ dan data multivariat dengan regresi logistik. 
HASIL

\section{Analisis Univariat}

Tabel 1. Distribusi Frekuensi Faktor-faktor yang Mempengaruhi WUS dalam Deteksi Dini Kanker leher Rahim di Puskesmas Babatan

\begin{tabular}{lcc}
\hline \multicolumn{1}{c}{ Variabel } & $\begin{array}{c}\text { Frekuensi } \\
(\mathbf{n = 8 7})\end{array}$ & Persentase (\%) \\
\hline Pengetahuan & & \\
Baik & 45 & 51,7 \\
Kurang & 42 & 48,3 \\
\hline Sikap & & \\
Positif & 39 & 44,8 \\
Negatif & 48 & 55,2 \\
\hline Keterpaparan & & \\
Informasi & 36 & 41,4 \\
Baik & 51 & 58,6 \\
Kurang & & \\
\hline Pendidikan & & \\
Tinggi & 45 & 51,7 \\
Rendah & 42 & 48.3 \\
\hline Deteksi Dini & & \\
kanker Leher & 25 & 28,7 \\
Rahim & 62 & 71,3 \\
Ya & & \\
Tidak & & \\
\hline
\end{tabular}

Berdasarkan tabel1 menunjukkan bahwa dari 87 WUS, sebagian besar $(51,7 \%)$ pengetahuan WUS baik, $(55,2 \%)$ sikap WUS negatif, $(58,6 \%)$ keterpaparan informasi WUS kurang, (51,7\%) pendidikan WUS tinggi dan $(71,3 \%)$ WUS tidak melakukan deteksi dini kanker leher rahim.

Tabel 2. Distribusi Umur WUS di Wilayah Puskesmas Babatan

\begin{tabular}{cccccc}
\hline Variabel & Mean & Median & Mode & SD & Min \\
& & & & & Max \\
Umur & 33 & 32 & 25 & 7,7 & $18-49$ \\
& & & & 38 & \\
\hline
\end{tabular}

Berdasarkan tabel 2. rata-rata umur WUS adalah 33 tahun, umur minimal 18 tahun dan maksimal 49 tahun.

Tabel. 3 Pengaruh Umur dengan Deteksi Dini Kanker Leher Rahim pada WUS di Wilayah Puskesmas Babatan

\begin{tabular}{cccccc}
\hline Umur & Mean & SD & SE & $\begin{array}{c}\text { P } \\
\text { value }\end{array}$ & N \\
\hline Tidak & 32,24 & 7,709 & 0,979 & 0,856 & 62 \\
$\begin{array}{c}\text { Deteksi } \\
\text { Dini } \\
\text { Deteksi } \\
\text { Dini }\end{array}$ & 34,88 & 7,639 & 1,528 & & 25 \\
\hline
\end{tabular}

\section{Analisis Bivariat}

Tabel 4. Faktor-Faktor yang Mempengaruhi WUS dalam Deteksi Dini Kanker Leher Rahim di Puskesmas Babatan

\begin{tabular}{|c|c|c|c|c|c|c|c|c|c|}
\hline \multirow{4}{*}{$\begin{array}{c}\text { Variabel } \\
\text { Independen }\end{array}$} & \multirow{4}{*}{ Kategori } & \multicolumn{4}{|c|}{ Deteksi Dini Kanker Leher } & \multirow{3}{*}{\multicolumn{2}{|c|}{ Total }} & \multirow{4}{*}{$\rho$} & \multirow{4}{*}{ OR } \\
\hline & & & & & & & & & \\
\hline & & \multicolumn{2}{|l|}{ Tidak } & \multicolumn{2}{|c|}{$\mathrm{Ya}$} & & & & \\
\hline & & $\begin{array}{c}n \\
(62) \\
\end{array}$ & $\%$ & $\begin{array}{c}\mathrm{n} \\
(25) \\
\end{array}$ & $\%$ & $\begin{array}{c}\mathrm{n} \\
(87)\end{array}$ & $\%$ & & \\
\hline \multirow[t]{2}{*}{ Pengetahuan } & Kurang & 36 & 85,7 & 6 & 14,3 & 42 & 100 & \multirow[t]{2}{*}{0,008} & \multirow[t]{2}{*}{4,385} \\
\hline & Baik & 26 & 57,8 & 19 & 42,2 & 45 & 100 & & \\
\hline \multirow[t]{2}{*}{ Sikap } & Negatif & 40 & 83,3 & 8 & 16,7 & 48 & 100 & \multirow[t]{2}{*}{0,012} & \multirow[t]{2}{*}{3,864} \\
\hline & Positif & 22 & 56,4 & 17 & 43,6 & 39 & 100 & & \\
\hline Keterpaparan & Kurang & 44 & 86,3 & 7 & 13,7 & 51 & 100 & 0,001 & 6,286 \\
\hline Informasi & Baik & 18 & 50,0 & 18 & 50,0 & 36 & 100 & \multirow{3}{*}{0,002} & \multirow{3}{*}{5,920} \\
\hline \multirow[t]{2}{*}{ Pendidikan } & Rendah & 37 & 88,1 & 5 & 11,9 & 42 & 100 & & \\
\hline & Tinggi & 25 & 55,6 & 20 & 44,4 & 45 & 100 & & \\
\hline
\end{tabular}

Tabel 4. menunjukkan bahwa dari 42 WUS yang pengetahuan kurang, hampir seluruh $(85,7 \%)$ tidak deteksi dini dengan nilai $\rho=0,008$ artinya ada hubungan pengetahuan dengan deteksi dini.Dari 48 WUS yang sikap negatif, hampir seluruh $(83,3 \%)$ tidak deteksi dini dengan nilai $\rho=0,012$ artinya ada hubungan sikap dengan deteksi dini. Dari 51 WUS yang keterpaparan informasi kurang, hampir seluruh $(86,3 \%)$ tidak deteksi dini dengan nilai $\rho=0,001$ artinya ada hubungan keterpaparan informasi dengan deteksi dini. Dari 42 WUS yang pendidikan rendah, hampir seluruh $(88,1 \%)$ tidak deteksi dini dengan nilai $\rho=0,002$ artinya ada hubungan pendidikan dengan deteksi dini. 


\section{Analisis Multivariat}

Analisis multivariat dilakukan untuk melihat variabel yang paling berhubungan terhadap deteksi dini kanker leher rahim di analisis dengan uji regresi logistik ganda didapatkan hasil sebagai berikut:

Tabel 5. Analisis Akhir Multivariat Dengan Variabel Keterpaparan Informasi Dan Pendidikan (Nilai $p<0,25$ )

\begin{tabular}{lll}
\hline Variabel & Nilai & $\operatorname{Exp}(\mathrm{B})$ \\
& $\mathrm{p}$ & \\
\hline Keterpaparan Informasi & 0,019 & 0,259 \\
Pendidikan & 0,052 & 0,300 \\
\hline
\end{tabular}

Berdasarkan tabel. 5 didapatkan hasil bahwa faktor yang paling dominan atau berpengaruh terhadap deteksi dini kanker leher rahim pada WUS adalah keterpaparan informasi dengan nilai $\rho=0,019$. Nilai $\mathrm{OR}=0,259$, artinya keterpaparan informasi tidak menjadi faktor penyebab melainkan faktor protektif dalam deteksi dini kanker leher rahim.

\section{PEMBAHASAN}

\section{Hubungan Pengetahuan dengan Deteksi Dini Kanker Leher Rahim}

Hasil analisis univariat menunjukkan sebagian besar $(51,7 \%)$ pengetahuan WUS baik. Penelitian Febriani (2016) didapatkan hampir seluruh $(98,1 \%)$ pengetahuan WUS baik. Berdasarkan penelitian ini, WUS sudah mengetahui pemeriksaan deteksi dini kanker leher rahim dengan metode IVA dan pap smear. Hasil analisis bivariat menunjukkan bahwa dari 42 WUS yang pengetahuan kurang, hampir seluruh $(85,7 \%)$ tidak deteksi dini kanker leher rahim. Hasil penelitian yang dilakukan Febriani (2016), seluruh WUS (100\%) yang pengetahuan kurang tidak deteksi dini kanker leher rahim. Berdasarkan hasil penelitian ini menunjukkan bahwa ada hubungan antara pengetahuan dengan deteksi dini kanker leher rahim pada WUS di wilayah Puskesmas Babatan.

\begin{tabular}{lccr}
\multicolumn{2}{c}{ Penelitian ini } & sejalan & dengan \\
penelitian Rahma & (2011) & yang \\
menunjukkan & ada & hubungan & yang
\end{tabular}
signifikan antara pengetahuan dengan minat WUS (wanita Usia Subur) dalam melakukan pemeriksaan IVA (Inspeksi Visual dengan pulasan Asam asetat) di Desa Pangebatan. Menurut penelitian Hong dkk (2013) wanita yang memiliki tingkat sangat rendah pengetahuan dan kesadaran kanker serviks, juga rendah dalam melakukan pemeriksaan papsmear. Hasil penelitiannya juga menunjukkan bahwa wanita dengan pengetahuan yang lebih baik dari kanker serviks lebih mungkin untuk melakukan pap smear.

Hasil penelitian Siti (2016) menunjukkan adanya hubungan antara pengetahuan tentang kanker serviks dengan kesediaan WUS dalam melakukan deteksi dini kanker serviks di Puskesmas Manahan Kota Surakarta $(\rho=0,025)$. Penelitian Gustina (2014) juga menunjukkan ada hubungan pengetahuan terhadap perilaku pencegahan kanker serviks $(\rho=0,045)$.

Hasil penelitian ini juga didapatkan hampir sebagian dari WUS $(57,8 \%)$ memiliki pengetahuan baik tetapi tidak deteksi dini dan sebagian kecil dari WUS $(14,3 \%)$ yang memiliki pengetahuan kurang, melakukan deteksi dini kanker leher rahim. Hal ini menunjukkan bahwa ada faktor lain yang mempengaruhi WUS dalam deteksi dini kanker leher rahim yaitu, sikap, dukungan suami, sosial ekonomi, keterjangkauan jarak, rasa takut, rasa malu dan faktor lainnya. Menurut penelitian Khosidah (2014) faktor agama atau keyakinan dan sosial budaya yang dianut wanita usia subur mempengaruhi keputusannya untuk tidak melakukan pemeriksaan deteksi dini kanker serviks.

\section{Hubungan Sikap dengan Deteksi Dini} Kanker Leher Rahim

Hasil analisis univariat menunjukkan sebagian besar $(55,2 \%)$ sikap WUS negatif. 
Hal ini sejalan dengan penelitian yang dilakukan Febriani (2016) didapatkan sebagian besar $(51,9 \%)$ sikap WUS negatif. Berdasarkan penelitian ini, WUS malu dan tidak mau melakukan pemerikaan deteksi dini dikarenakan pemeriksaan dilakukan pada organ kewanitaan bagian dalam. Hasil analisis bivariat menunjukkan bahwa dari 48 WUS yang sikap negatif, hampir seluruh $(83,3 \%)$ tidak deteksi dini kanker leher rahim. Hasil penelitian ini sesuai dengan penelitian yang dilakukan Febriani (2016) hampir seluruh $(86,2 \%)$ sikap WUS negatif, tidak deteksi dini kanker leher rahim. Berdasarkan hasil penelitian ini menunjukkan bahwa ada hubungan antara sikap dengan deteksi dini kanker leher rahim pada WUS di wilayah Puskesmas Babatan.

Hasil penelitian ini juga didapatkan sebagian besar dari WUS $(56,4 \%)$ memiliki sikap positif tetapi tidak deteksi dini dan sebagian kecil $(16,7 \%)$ WUS yang memiliki sikap negatif melakukan deteksi dini kanker leher rahim. Hal ini terjadi karena banyak faktor yang mempengaruhi bukan hanya dilihat dari sikap saja, menurut Green (2005) ada faktor (pengetahuan, keterjangkauan jarak, keterjangkauan biaya, dukungan suami, kader, dan keluarga) yang dapat mempengaruhi WUS dalam deteksi dini kanker leher rahim.

Berdasarkan penelitian Sarini (2011) yang mengatakan bahwa tidak semua wanita yang bersikap positif melakukan deteksi dini kanker leher rahim.Hasil penelitian yang dilakukan Febriani (2016) bahwa sikap positif dari individu tidak serta merta berujung pada perilaku kesehatan yang baik pula, dalam hal ini adalah melakukan IVA atau papsmear.

\section{Hubungan Umur dengan Deteksi Dini Kanker Leher Rahim}

Hasil analisis univariat menunjukkan bahwa dari 87 WUS, rata-rata umur WUS adalah 33 tahun.Hasil uji Independent sampel T Test menunjukkan bahwa tidak ada pengaruh antara umur dengan deteksi dini kanker leher rahim pada WUS di wilayah Puskesmas Babatan. Hasil Penelitian ini sejalan dengan penelitian Gustina dkk (2014) didapatkan tidak ada hubungan umur terhadap perilaku pencegahan kanker serviks ( $\mathrm{p}$ value $=$ 0,306 ).

Hasil penelitian Yuliwati (2012) juga menunjukkan tidak ada hubungan yang signifikan antara umur dengan deteksi dini kanker serviks.Hal ini bisa dikaitkan dengan kerentanan terhadap penyakit.Pada penelitian ini didapatkan mayoritas WUS berumur kurang dari 40 tahun sehingga merasa belum rentan terhadap kanker serviks.Secara psikologis seseorang akan banyak melakukan tindakan pencegahan karena merasa lebih rentan terhadap penyakit (Sarafino, 2004).

Kasus kejadian kanker leher rahim paling tinggi terjadi pada usia 40 dan 50 tahun. Maka pemeriksaan Deteksi Dini Kanker Leher Rahim dianjurkan pada perempuan berusia 30 - 50 tahun, karena lesi pra kanker lebih mungkin terdeteksi, yaitu biasanya 10 sampai 20 tahun lebih awal (Depkes RI, 2007). Semakin dewasa umur seharusnya semakin matang dalam berfikir dan akan semakin bijaksana dalam melakukan deteksi dini kanker leher rahim. Namun tidak menutup kemungkinan bahwa usia individu yang diharapkan kedewasaan dan pemikirannya pun sepadan dengan usianya, justru menolak menyadari dan dengan rendah hati mau melakukan deteksi dini. Oleh sebab itu dibutuhkan peran petugas kesehatan untuk dapat memberikan informasi yang benar, tepat dan sesuai dengan usia WUS sehingga termotivasi untuk dapat melakukan deteksi dini kanker leher rahim.

\section{Hubungan Pendidikan dengan Deteksi Dini Kanker Leher Rahim}

Hasil analisis univariat menunjukkan sebagian besar $(51,7 \%)$ pendidikan WUS tinggi. Penelitian Febriani (2016) 
didapatkan hampir sebagian (48,9\%) pendidikan WUS tinggi. Hasil analisis bivariat menunjukkan bahwa dari 42 WUS yang pendidikan rendah, hampir seluruh $(88,1 \%)$ tidak deteksi dini kanker leher rahim. Hasil penelitian ini sesuai dengan penelitian yang dilakukan Febriani (2016) hampir seluruh $(88,1 \%)$ pendidikan WUS rendah, tidak deteksi dini kanker leher rahim. Berdasarkan hasil penelitian ini menunjukkan bahwa ada hubungan antara pendidikan dengan deteksi dini kanker leher rahim pada WUS di wilayah Puskesmas Babatan.

Penelitian ini sesuai dengan penelitian yang dilakukan oleh Nasihah dan Lorna (2013) ada hubungan antara pendidikan dengan pelaksanaan deteksi dini kanker servik melalui IVA dengan nilai $\mathrm{p}$ value $=0,000$. Hasil penelitian Rahma (2011) juga menunjukkan ada hubungan yang signifikan antara pendidikan dengan minat WUS (wanita Usia Subur) dalam melakukan pemeriksaan IVA (Inspeksi Visual dengan pulasan Asam asetat) di Desa Pangebatan.

Menurut Wawan dan Dewi (2010), pendidikan dapat mempengaruhi seseorang untuk membentuk pola hidup, terutama dalam memotivasi sikap untuk berperan serta dalam pembangunan kesehatan.Semakin tinggi tingkat pendidikan seseorang maka semakin mudah dalam menerima informasi, sehingga semakin banyak pula pengetahuan yang dimiliki.Sebaliknya pendidikan yang kurang akan menghambat perkembangan sikap seseorang terhadap nilai-nilai yang baru dikenal. Menurut Mitchell (2014) Skrining harus ditargetkan dan diprioritaskan untuk perempuan dengan tingkat pendidikan yang lebih rendah.

Hasil penelitian ini juga didapatkan sebagian besar dari WUS $(55,6 \%)$ memiliki pendidikan tinggi tetapi tidak deteksi dini dan sebagian kecil $(11,9 \%)$ WUS yang memiliki pendidikan rendah melakukan deteksi dini kanker leher rahim.
Hal ini dapat disebabkan oleh banyak faktor yaitu sikap, pengetahuan, keterpaparan informasi, dukungan suami dan keluarga, sehingga WUS akan melakukan deteksi dini kanker leher rahim.

\section{Hubungan Keterpaparan Informasi dengan Deteksi Dini Kanker Leher Rahim}

Hasil analisis univariat menunjukkan sebagian besar $(58,6 \%)$ keterpaparan informasi WUS baik. Hal ini sesuai dengan penelitian Febriani (2016) didapatkan sebagian besar (58\%) keterpaparan informasi WUS baik.Analisis bivariat menunjukkan bahwa dari 51 WUS yang keterpaparan informasi kurang, hampir seluruh $(86,3 \%)$ tidak deteksi dini kanker leher rahim. Hasil penelitian ini sesuai dengan penelitian yang dilakukan Febriani (2016) hampir seluruh $(89,5 \%)$ WUS yang tidak mendapatkan informasi tidak deteksi dini kanker leher rahim.Berdasarkan hasil penelitian ini menunjukkan bahwa ada hubungan antara keterpaparan informasi dengan deteksi dini kanker leher rahim pada WUS di wilayah Puskesmas Babatan.

Informasi tentang manfaat melakukan tes IVA harus senantiasa disosialisasikan agar dapat meningkatkan kesadaran WUS untuk melakukan tes IVA. Jika persepsi terhadap ancaman kanker leher rahim tinggi dan persepsi akan keuntungan untuk melakukan deteksi dini kanker serviks melebihi dari persepsi akan hambatan yang akan diperoleh, maka dapat mendorong seseorang untuk melakukan deteksi dini kanker serviks secara rutin.

Hasil penelitian ini sejalan dengan penelitian Nuraprianti M (2015) sumber informasi memiliki pengaruh positif dan signifikan dengan perilaku pemeriksaan pap smear dalam upaya deteksi dini kanker serviks oleh wanita usia subur (WUS) di Puskesmas Bungursari Purwakarta.

Informasi yang peroleh tentang kanker leher rahim dapat diperoleh melalui penyuluhan oleh tenaga kesehatan melalui pertemuan di pengajian, pertemuan di 
tingkat desa, informasi dari teman atau tetangga maupun keluarga yang pernah melakukan pemeriksaan deteksi dini kanker leher rahim selain itu informasi juga dapat diperoleh melalui sarana komunikasi.

Hasil penelitian ini juga didapatkan setengah dari WUS (50\%) memiliki keterpaparan informasi baik tetapi tidak deteksi dini dan sebagian kecil dari WUS $(13,7 \%)$ yang memiliki keterpaparan informasi kurang, melakukan deteksi dini kanker leher rahim.

Menurut hasil penelitian Febriani (2016) bahwa sebagai sarana komunikasi, bebagai media massa seperti televisi, radio, mempunyai pengaruh besar dalam pembentukan opini dan kepercayaan orang. Adanya informasi baru mengenai sesuatu hal memberikan landasan kognitif baru bagi terbentuknya sikap terhadap hal tersebut.Pesan-pesan sugestif yang dibawa infomasi tersebut.Dalam hal ini perilaku deteksi dini kanker leher rahim pada WUS juga dipengaruhi apakah wanita tersebut

\section{DAFTAR RUJUKAN}

Febriani, CA. 2016. Faktor-faktor yang Berhubungan dengan Deteksi Dini Kanker Leher Rahim di Kecamatan Gisting Kabupaten Tanggamus Lampung. Jurnal Kesehatan. Vol.VII, hlm 228-237.

Gustina, Dwikha, dkk. 2014. Faktor-Faktor yang Berhubungan dengan Perilaku Pencegahan Kanker Serviks pada Wanita Usia Subur. JOM PSIK Vol.1 No.2 Oktober 2014

Khosidah, A \& Trisnawati, Y. 2015. Faktor-faktor yang Mempengaruhi Ibu Rumah Tangga dalam Melakukan Tes IVA sebagai Upaya Deteksi Dini Kanker Serviks. Jurnal Ilmiah Kebidanan. Vol.6 No.2, hlm.94-105.

Mitchell, SM. 2014. Factors associated with highrisk HPV positivity in a low-resource setting in sub-Saharan Africa. American Journal Obstetri Gynecologi; 210:81.e1-7.

Nasihah, M \& Lorna, S. 2013. Hubungan antara Pengetahuan dan Pendidikan dengan Pelaksanaan Deteksi Dini Kanker Serviks Melalui IVA. Jurnal Midpro edisi 2: 20-26. sudah pernah mendapat informasi tentang hal tersebut atau belum.

\section{KESIMPULAN}

Berdasarkan hasil penelitian faktorfaktor yang mempengaruhi WUS dalam deteksi dini kanker leher rahim di wilayah Puskesmas Babatan, maka dapat disimpulkan bahwa sebagian besar dari WUS di wilayah Puskesmas Babatan memiliki pengetahuan baik, sikap negatif, keterpaparan informasi yang kurang dan pendidikan tinggi.Ada hubungan yang bermakna antara pengetahuan, sikap, pendidikan dan keterpaparan informasi dengan deteksi dini kanker leher rahim pada WUS di wilayah Puskesmas Babatan. Tidak ada hubungan yang bermakna antara umur dengan deteksi dini kanker leher rahim pada WUS di wilayah Puskesmas Babatan. Faktor yang paling dominan atau berpengaruh terhadap deteksi dini kanker leher rahim pada WUS adalah keterpaparan informasi.

Nuraprianti M. 2015. Perilaku Pemeriksaan Pap smear dalam Upaya Deteksi Dini Kanker Serviks oleh Wanita Usia Subur (WUS) di Puskesmas Bungursari Purwakarta. Jurnal Ilmiah Kesehatan. Vol.14 No.2.18-25

Siti, Indah. 2016. Faktor-faktor yang Mempengaruhi Kesediaan WUS dalam Melakukan Deteksi Dini Kanker Serviks di Puskesmas Manahan Surakarta.

Syarifudin, B. 2010. Panduan TA Keperawatan dan Kebidanan dengan SPSS. Yogyakarta: Grafindo Litera Media.

Tarigan, FL. 2014. Faktor-faktor yang Berhubungan dengan Perilaku WUS dalam deteksi Dini Kanker Serviks di Kelurahan Dwikora Medan.

Wawan, A dan Dewi. 2010. Teori dan Pengukuran Pengetahuan dan Perilaku Manusia. Yogyakarta : Nuhu Medika.

Wilgin, Christin et all. 2011. Skrining Kanker serviks dengan IVA dan Model Aplikasi di Lapangan. Jakarta : FK UI. 